\title{
Distal Bile Duct Cancer pT1 TNM Finding v8
}

National Cancer Institute

\section{Source}

National Cancer Institute. Distal Bile Duct CancerpT1 TNM Finding v8. NCI Thesaurus.

Code C134800.

Distal bile duct cancer with tumor invading the bile duct wall with a depth less than $5 \mathrm{~mm}$.

(from AJCC 8th Ed.) 